\title{
THE STOCK EXCHANGE SPECIALIST: AN ECONOMIC AND LEGAL ANALYSIS
}

\author{
Nicholas Wolfson* aNd ThOMas A. RusSo**
}

\section{INTRODUCTION}

The Specialist as a member of a stock exchange has two functions. ${ }^{1} \mathrm{He}$ must execute orders which other members of an exchange may leave with him when the current market price is away from the price of the orders. By executing these orders on behalf of the other exchange members when the market price reaches the price stated on these orders, ${ }^{2}$ the specialist makes it possible for these members to perform their business elsewhere on the Floor. In handling these orders, the specialist acts as broker or agent. In addition to the brokerage functions, however, he has historically had the additional function of acting as dealer or principal for his own account. Under current rules and regulations of the exchanges and the Securities and Exchange Commission, purchases and sales for his own account must be made, insofar as reasonably practicable, with a view to assuring a fair and orderly market in the stocks which he services. Moreover, whenever there are public buyers but no public sellers, or public sellers but no public buyers, he is expected, within reasonable limits, to buy or sell for his own account in order to decrease price differences between transactions and to add depth to

* Assistant Director, Division of Trading and Markets, Securities and Exchange Commission. A.B. 1953, Columbia University; J.D. 1956, Harvard University.

** Staff Attorney, Division of Trading and Markets, Securities and Exchange Commission. A.B. 1965, Fordham University; M.B.A. 1969, J.D. 1969, Cornell University.

The Securities and Exchange Commission, as a matter of policy, disclaims responsibility for any private publication by any of its employees. The opinions expressed in this article are those of the authors and do not necessarily reflect the views of the Securities and Exchange Commission or of the authors' colleagues upon the staff of the Commission.

1. For general discussions of the functions of specialists and the procedures utilized in their operations, see G. LefFler, The Stock Market 203-18 (3d ed. 1963); NYSE, Now, About the Specialist . . . (1969); B. Shultz, The Securities Market-AND How It Works 12452 (rev. ed. 1963). See also SEC, Report of SPECial Study of Securities Markets of the Securtties and Exchange Commission, H.R. Doc. No. 95, 88th Cong., Ist Sess., pt. 2, at 57 I71 (1963) thereinafter cited as SpECIAL StUdy]; E. Wheeler \& F. Graham, The Specialist Firm. in The Stock Market HaNdBooK $911-15$ (G. Kerekes \& F. Zarb ed. 1970).

2. See generally B. ShuLrz, supra note 1 , at $95-99$. The specialist has traditionally maintained a loose-leaf notebook or "book" for recording outstanding orders, but the NYSE is currently considering modernizing the "book" with an electronic system utilizing a televisionlike display. NYSE ANNUAL REPORT 20 (1969). 
the market. He performs both functions for a limited number of issues assigned to him by the stock exchange. ${ }^{3}$

\section{Historical OVERVIEW}

In 1935 the Twentieth Century Fund's study of the securities market roncluded that:

Specialists, as well as other exchange members, should be permitted to function either as traders or as brokers, but not as both. . . . No specialist, or other broker, should be permitted to have any interest in any trading account, pool, syndicate, underwriting operation or option.'

The Fund's basis for this conclusion was its belief that "the services rendered by the specialist are not of sufficient value to warrant the continuation of a condition where a small group of persons is given a preferred position in the market."

One year later the Securities and Exchange Commission in studying the same system reached the conclusion that insufficient data had been presented to justify the segregation of functions. ${ }^{6}$ In 1941 Professor Vernon, then a member of the Commission staff, suggested an alternative to considering the specialist in terms of his general beneficial or detrimental effect on the market as both the Twentieth Century Fund and Segregation Report had done. He stated that the feasibility of regulating the specialist should be viewed

in terms giving recognition to the possibility that his job may vary in different types of stocks . . . [T] he dealer role of specialists may be necessary and justifiable for one set of stocks, providing sufficient grounds for overlooking his advantage over the public as a dealer in such issues, while his dealer position in another group of stocks runs contrary to the public interest.?

In actively traded issues where a sufficient number of buyers and sellers exists to assure a continuous market with each sale price related to the prior sale, Vernon reasoned, little justification for the specialist function exists. He recognized the need for greater study to

3. Certain inactively traded securities are designated as "cabinet" securities. Bids and offers are written on cards which are filed in the "cabinet." When a bid and offer match, the respective members are notified, and the trade is consummated. For rules relating to these cabinet securities, see New York Stock Exchange [hereinafter cited as NYSEl 1 ule 85.

4. The Twentieth Century Fund, InC., The Security Markets 685 (1935).

5. Id. at 684.

6. SEC, Report on the Feasibility and AdVISABILITy of the Complete Segregation of the Functions uf Dealer and Broker 109 (1936) thereinafter cited as Segregation REPORT].

7. R. Vernon, The Regulation of Stock Exchange Members 96 (1941) thercinafter cited as VERNON]. 
effectively develop such segmented rules regulating the specialist's activity.

Little was written on the specialist system in the exhaustive manner of the Twentieth Century Fund, the Segregation Report, and Vernon's book until 1963 when the Commission's Special Studys reported that "in its present form, [the specialist system] appears to be an essential mechanism for maintaining continuous auction markets and, in broad terms, appears to be serving its purposes satisfactorily." With the adoption of rule $1 \mathrm{lb}-1^{10}$ which recognized both the dealer and broker functions of the specialist, the issue seemed finally settled, at least from a legal standpoint, that the specialist system's beneficial effects surpassed any defects.

\section{ECONOMic Role of THE SPeCialist}

Several important questions should be examined to acquire an understanding of the economic motivations present in the specialist system and of the impact of the specialist on market prices. To what extent is the specialist's monopolistic or oligopolistic power to administer the price of his specialty stock limited by his obligation to maintain a fair and orderly market? Can a specialist be a speculator and still meet this obligation? What do the terms "fair market" and "orderly market" mean?

In any economic categorization of the specialist's function, the specialist's position as the price administrator of his specialty stock requires analysis. To the extent that he is a sole ${ }^{11}$ price administrator, he may be considered a monopolist. ${ }^{12}$ Professor Baumol comments

8. In 1962 the Commission staff finished an extensive study of the specialist system on the American Stock Exchange [hereinafter cited as Amex]. SEC, STAFF REPORT ON Organization, Managenient, and Regulation of Conduct of Members of the AMERican StocK EXChaNGe (1962).

9. Special Study, pt. 2, at 167.

10. 17 C.F.R. 240.1lb-1 (1970).

11. Although each NYSE stock currently utilizing the specialist sytem has only one specialist, this was not always the case. The Segregation Report noted that in 1936 "stocks which enjoy considerable trading activity have as many as six competing specialists." SEgREgation RePORT 26. At the time of the Special Study a "few of the [specialist] units [were] registered in the same stocks and compete[d] with each other." SPECIAL. STUDY, pt. 2, at 67.

12. One economist, Harold Demsetz, stated that while some believe that "scale economics" exist with respect to the specialist suggesting a "natural monopoly," there are many sources of competition to the specialist. Demsetz, The Cost of Transacting, 1968 QUARTERLY JOURNAL OF ECONOMICs 33, 42. Listing the main types of competition as "(1) rivalry for the specialist's job, (2) competing markets, (3) outsiders who submit limit orders rather than market orders, (4) foor traders who may bypass the specialist by crossing buy and sell orders themselves, and (5) 
that "the specialist must be treated not as a competitor, but, on the contrary (at least for a narrow 'normal' price range) as a price administering monopolist or oligopolist."13 In part his conclusion depends on the assertion that the specialist knows the demand and supply curves through his "book" and can "choose to end up at the spot which is most favorable to him from among all the points that constitute the market's offer curve."14

Any economic analysis of the specialist's role must also consider the obligations of the specialist both under the securities laws and the applicable rules of the stock exchanges. While economic theory is practically limited by the specialist's legal obligation, that theory should be influential in interpreting or formulating particular rules within the legal framework. Since obligations may differ as the time period is lengthened, the specialist's economic role can be classified into three time periods: short, intermediate, and long run. The unique nature of the specialist's function suggests a fourth classification-sudden price fluctuations. While the latter category

other specialists [in other securities]," id. at 43 , he concluded that "an enumeration of the forces of competition is not by itself, convincing evidence of competition; the large share of trading in which the specialist does not participate is somewhat more convincing of the absence of 'natural monopoly' conditions." Though not specificially mentioned by Demsetz in his consideration of his second competitive force (competing markets), a number of over-the-counter market makers in listed securities (commonly called "the third market") compete with the specialist. See generally Comments of Wceden and Co. on SEC Release No.8791 (Feb. 12, 1970). However the impact of this third market competition may be somewhat limited in that (1) the transactions are not publically reported and (2) a large percentage of the volume in this market is in relatively large blocks of stock which many argue are not part of the normal specialist auction market system. Sce text at notes 155-59. See generally R. Doede, The Monopoly Power of the New York Stock Exchange (Ph.D. thesis at University of Chicago).

13. W. Baumol, The Stock Market and Economic Efficiency 22 (1965). The term "monopolists" is defined as the individuals "who "administer' prices in a manner which promotes their profit" as opposed to "competitors" who "determine their purchases in accord with an independently established demand schedule . . . whose variable is price." Id. at 23 n.12.

14. Id. The economic value of the "book" is a disputed issue. Without doubt it is "an indicator of public interest in a particular security." SPECIAL STUDY, pt. 2, at 76. However, many argue that the "book" often indicates the opposite of what one might expect-a book with many sell orders may suggest a possible price rise since many sophisticated investors who expect a price rise have placed sell limit orders in the book to take advantage of the anticipated rise. If this theory is correct, the "book" may signal the direction a stock might be heading but not through a traditional analysis of a supply and demand curve. Id. Moreover, to the extent large blocks are not shown to the specialist, he may not be aware of the true supply and demand curve.

Vernon suggested that orders in the "book" do not create trends but indieate the level of resistance that must be met by price movement. VERNON 66 n.14. Sce also Business WeEk, May $9 ; 1970$, at 108. 
generally occurs within the short run, it warrants special attention because it involves unique legal and economic considerations. ${ }^{15}$

\section{Short Run}

The primary emphasis on the role of the specialist has always been on his short run value to the market. ${ }^{16} \mathrm{He}$ is obligated to reduce temporary disparities between supply and demand in order to facilitate a fair and orderly market. However, the meaning of "temporary disparities" is unclear, since the time duration of the specialist's short run obligation may depend upon the particular facts of the situation. Arguably, in certain instances, his obligation may be for only a few hours or less if his economic capability as a dealer is threatened by a deluge of orders. Thus the specialist's obligation to maintain a fair and orderly market is limited in the sense that no one expects him to go bankrupt performing his daily duties. His monopolist's or oligopolist's role is further limited since the direction in which he is obligated to administer the price of his specialty stock is against the market trend. To evaluate the specialist's performance the NYSE uses the "tick test" to determine if he is acting to maintain a fair and orderly market. ${ }^{17}$ By this test, specialist purchases below and sales above the last different price are deemed stablizing and therefore proper. ${ }^{18}$

The specialist has a certain amount of discretion in exercising his short run obligation. In some situations, he has no choice but to enter the market as dealer and consequently is obliged to be a price administrator. Other situations, however, do not necessarily require

15. Professor Baumol suggests that four tasks should be considered in an economic analysis of the stabilization function of the specialist including:

(1) reduction in the magnitude of long-term price trends; (2) reduction in the magnitude of very short-tcrm oscillations resulting from the discontinuous flow of supplies and demands (in thin markets); (3) reduction in the amplitude and frequency of other price fluctuations of moderate amplitude; (4) reduction in the magnitude of sudden price moves which constitute temporary crises. W. BAUMOL, supra note 13, at 30-31.

The specialist is not expected to affect long run prices (task 1) but does have an obligation to maintain a continuous market (task 2). The problem, according to Baumol, lies in tasks 3 and 4. In sudden price movements (task 4), as at the time of President Eisenhower's heart attack, the specialist may be driven by his own self-interest to play the role of stabilizer to the extent he feels the price of the stock will rebound and hence assure him a quick profit.

16. See generally NYSE, Now, ABOUT THE SPECIALIST . . . (1969).

17. Other tests include the participation ratio and the carry-over position. See generally $S$. Robiins, The Securities MARKets 197 (1966); Special Study, pt. 2, at 101-06.

18. For additional explanation see S. RobBins, supra note 17, at 196-97. To the extent the "tick test" is used to demonstrate whether the specialist is administering prices against the 
his entry into the market nor do they foreclose his participation. For example, if the highest bid on the "book" is for 100 shares at 20 and the lowest public offer is at $203 / 8$, the specialist might in certain cases have discretion to either place his own bid or withhold himself from the market. If the situation were changed so that the lowest offer was at 24 , making the spread four points, the specialist would be obliged to enter the market as dealer. In this instance he would be required to administer the price of the stock. But depending on numerous considerations including the last sale price of the stock, competition from both regional stock exchanges and the third market, and volatility of the stock, he has a certain amount of discretion in determining how to enter the market-as a bidder, offeror, or both-and at what price. Hence, even when he is under an obligation to administer the price of the stock, the manner in which he exercises this obligation is somewhat discretionary so long as his action ultimately promotes a fair and orderly market. It should be noted that while many monopolists and oligopolists are regulated as to the price they may charge, the specialist, because of the very nature of the "free market," could not be so regulated.

In considering the specialist's short run value to the market, a problem arises in determining when "temporary disparities between supply and demand" cease to be temporary. The answer arguably appears after the situation has occurred, making the short run obligation as nebulous as the actions of market prices themselves.

\section{Sudden Price Changes}

The possibility of sudden large shifts in market prices provides a major justification for the specialist's existence. The shift may result on an individual stock-by-stock basis due to a public announcement by management or from a sudden rise or decline in the general market. While suspension of trading in the specialist's stock or in all

market trend, it applies by its very nature only on a trade-by-trade analysis. Hence, it is possible that a specialist could, in the course of an hour, a day, or a wcek satisfy the "tick test" and yet be a net seller in a down market or a net buyer in an up market. For example, in an "up" rising market there are still numerous minus ticks. As a result, he could limit his purchases to such minus ticks and appear to be stabilizing when in fact he would be accelerating a rising market. See id. at 198-99. In such a case, his obligation to promote a fair and orderly market might not be satisfied. The "tick test" may also be satisfied by a random sequence of orders rather than conscious specialist action. SpECIAL STUDY, pt. 2; at 102. Although the exchanges have devised various tests such as the "tick test" to measure stabilization, the difficulty in defining the term "stabilization" makes the task difficult. 
stocks will release the specialist from his obligation, ${ }^{19}$ a considerable economic dislocation will undoubtedly occur between the influx of orders and the eventual suspension of trading. In the interim the specialist is expected to add depth and liquidity to a market which would otherwise be devoid of these characteristics. In two previous sharp declines specialists have been net purchasers, but their participation probably depended not only upon their obligation but upon their economic outlook. Although specialists were net buyers immediately after President Eisenhower's heart attack and during the sharp market decline of May 28, 1962, their stabilization effect on these two occasions differed greatly.$^{20}$ According to the Special Study, one reason for the lack of substantial purchases by the specialists on May 28 was their belief that this decline was non-temporary in nature. ${ }^{21}$ The stabilizing effect of the specialists on May 28 was widely publicized by the NYSE, implying that at least the Exchange felt that most specialists had met their obligations. ${ }^{22}$ The emphasis placed on net purchases by both the NYSE and the Special Study indicates that the characterization of the specialist as a stabilizing monopolist or oligopolist definitely includes the daily periods of sudden price movement. The extent to which the specialist must meet this obligation is difficult to determine; numerous factors including his capital status must be considered. ${ }^{23}$ The Special Study commented; "Obviously, no one person has the capital to stem a selling wave such as that of May 28, but with his central location, the specialist is in a position to cushion the public's selling by giving depth to the markets . . . .'24

19. NYSE rule 47 provides: "Floor Officials shall have power to supervise and regulate active openings and unusual situations that may arise in connection with the making of bids, offers or transactions on the Floor." NYSE rule 51 empowers a majority of the Chairman, Vice-Chairman, and the senior Floor Governor to suspend trading in all securities whenever such suspension would be in the public interest.

20. During the former decline, specialists were net purchasers of 595,550 shares, representing 20.4 percent of their total purchases and sales. During the May 28, 1962 decline they were nct purchasers of only 206,400 shares, representing 6.7 percent of their total purchases and sales. Special STUdY, pt. 2, at 112-13.

21. Id. at 113 .

22. Id. at 97 .

23. The additional factors requiring consideration include the price of the stock, the volatility of the stock, and the specialist's present position in the stock. See note 7l infra.

24. Special Study, pt. 2, at 121. 


\section{The Intermediate and Long Run}

The specialist's obligation to stabilize the market is reduced as the long run is approached. Indeed, if such an obligation exists in the long run, the auction market would be a manipulated, rather than a free, market. The terms used to describe the specialist's function- "fair and orderly market;" "temporary disparities between supply and demand;" "liquidity and continuity:" - as well as the "tick test" and the limited capital requirement of the specialist place emphasis on the specialist's economic role over the short run. ${ }^{25}$

Regardless of the duration of the specialist's obligation, economic analysis of the specialist's role must necessarily consider Congress' two basic aims that the stock market be "fair" and "orderly."20 Professor Vernon commented:

A "fair" market . . . bears the connotation of a market in which the individual investor need not fear for the integrity of his broker, the safety of his funds, or the possibility that price movements are being artificially controlled. An "orderly" market is regarded as one in which there are no "sudden and unreasonable fluctuations in the prices of securities" and consequently a market which makes no unnecessary adverse contribution to the stability and well-being of the public at large. The two major functions of regulation, therefore, are carefully distinguished; the goal of fairness, directed primarily at the protection of the individual, may be looked upon as something in the naturc of a police function, while the "orderly market" aim, an aim intended to

25. In this connection, two commentators stated:

The whole of the market is not necessarily the sum of its parts. Each individual transaction by a specialist may have little impact on intermediate-term price trends if, as the New York Stock Exchange proclaims, he acts merely to narrow the spread. On the other hand, his overall impact is not necessarily neutral. This is particularly so to the degree that technicians dominate the market, when specialists may set the tone for price movements weeks ahead by strategic buying and selling, even without taking a significant long or short position.

Where fundamentals are the major determinants of market decisions, the specialist can exercise little influence on intermediate-term price movements. But when technical factors assume a dominant role for individual stocks, he becomes more than a mere catalytic intermediary. By helping to build a chart pattern, by "reinforcing a hold point" or permitting his stock to "penetrate a support level," he can alter, as well as simply react to, an externally determined supply and demand, and can be instrumental in mapping its future price course for the forthcoming weeks. James \& James, Dispured Role of the Stock Exchange Specialist, 40 HARV. Bus. Rev. 133, 141-42 (1962).

26. One of the purposes of the Securities Exchange Act is to "insure the maintenance of fair and honest markets ...." Securities Exchange Act of $1934 \S 2,15$ U.S.C. $\S 78 \mathrm{~b}$ (1964) [hereinafter cited as 1934 Act]. The Commission rules regulating specialists should "restrict his dealings . . . to those reasonably necessary to permit him to maintain a fair and orderly market." 1934 Act $\S 11(b), 15$ U.S.C. $\$ 78 k$ (b) (1964). In connection with excessive off-floor trading by members of the Exchange the standard of "a fair and orderly market" is also used. 1934 Act $\S I 1(a), 15$ U.S.C. $\S 78 \mathrm{k}$ (a) (1964) (emphasis added in all quotations). 
benefit the general public interest, is more suggestive of the use by Government of economic controls.

Clearly, [orderly market] was intended in some way to represent a market which was free from "excessive speculation," a type of speculation which, we are told, results "in sudden and unreasonable fluctuations in the prices of securities."zz

No agreement exists concerning the effect of speculation on stock prices. Under one theory, the speculator stabilizes prices by purchasing or selling as necessary to move prices toward an equilibrium position. A contrary theory assumes that the speculator will continue to follow trends past the equilibrium. Under the latter hypothesis the mere presence of traders in the market can accentuate, rather than dampen, fluctuations. ${ }^{28}$ Thus generalities are not possible.

Not all speculators follow, or in the case of specialists, should be permitted to follow, a destabilizing pattern. The "bad" speculator aggravates price trends by going with the trend; the "good" speculator goes against the trend, thereby adding stability to the market. ${ }^{29}$ The "bad" speculator may have prompted Congress" adoption of the "orderly market" standard. To the extent that the specialist is not permitted to buy or sell except to promote a fair and orderly market, he is prevented, at least on a trade-by-trade basis, from being a "bad" speculator. Thus, the scope of his obligation

27. VERNON 132-35.

28. Stock market speculation has been described as follows:

Although speculation may actually stabilize prices, the writer is at a loss to find any $a$ priori reason why it should do so . . . . The speculator's concern is to make money out of the movements of prices. The argument that speculation stabilizes is based on the tacit assumption that the only movements which interest him are those in the direction of the equilibrium price. The speculator is supposed, for instance, to refrain from selling and to buy when the price is below the equilibrium figure. This will tend to send it up or to stop its descent. When the equilibrium figure is reached, he will sell again and check the rise. But, if the price is rising, why should he sell at that particular point? Why should he not rather buy more, or at least refrain from selling, and by so doing give added impetus to the movement? ...

Indeed, it seems more likely that speculation would cause more and greater fluctuations. The very presence in the market of large numbers of traders whose purchases and sales ultimately cancel out brings capricious shifts in demand and supply as all flock one way and then the other. Every movement must be accentuated by the attempts of speculators to take advantage of it. As the movement slows down or stops, anxiety to realize on their profits and to lay the basis for new ones may stop it completely and turn it the other way, whereupon it will gain momentum again by the very actions of the speculators themselves. E. CHAMBERLIN, THEORY OF MONOPOLISTIC COMPETITION 29 (1933).

29. The impact of speculation has been considered under the subject of "theories of withholding." See C. Hardy, Odd-Lot Trading on the New York Stock Exchange 68-69 (1939). On the "good" and "bad" speculator, see VERNON 134-42. 
under the applicable rules of his exchange and the obligation imposed by the 1934 Act and Commission rules thereunder are of importance in limiting instability due to speculation. ${ }^{30}$

Some economists, including Professor Stigler, believe that the specialist's ability to "predict changes in equilibrium prices, or, in other words, how closely does he keep bid and ask prices to the levels which in retrospect were correct' 31 should be a criterion for judging his efficiency. To the extent specialists are able to estimate the future course of events they would "smooth the path of the price quotations." ${ }_{32}$ Hence, the specialist's own profit motive as a speculator, rather than any imposed obligation, would enable him to perform his economic and legal roles. Stigler further criticized the suspension of trading in a stock in an emergency situation, believing that the mechanics of speculation would work as effectively here as in a normal market.

Some disagreed with Stigler's approach. Considering the proposed standard of market efficiency - the success of the speculator in judging changes in equilibrium prices-commentators argued that Stigler

implicitly assumes that speculators do not affect equilibrium price, so that the existence of speculative profits is necessarily a reflection of the success af speculators in anticipating movements in equilibrium price . . . This is a basic assumption . . . without justification . . . . [T]here are both theoretical and empirical grounds for believing that the demand schedule of investors in the stock market is greatly influenced by price movements, so that speculators can profit substantially by trading actively which is destabilizing. For example, if speculators make heavy net purchases of a security in a period when its equilibrium price has risen moderately as a result of favorable financial news, their activity may drive the price much higher than it would otherwise have gone.33

Replying to this criticism, Stigler stated that he did consider the effect of the speculator's activity by assuming "that the speculator's balances are equal at the beginning and at the end of a speculative interval." ${ }^{34}$ The rebuttal to Stigler's reply concluded that Stigler's

30. The specialist's obligations will be discussed in greater detail below. Sec text accompanying notes 38-60 infra.

31. Stigler, Public Regulation of the Securities Markets, 1964 J. Bus. 133.

32. Id.

33. Friend \& Herman, The S.E.C. Through a Glass Darkly, 1964 J. Bus. 382, 400. This type of speculation seems to be the type labelled by Vernon as "bad speculation." Sec text at notes 29-32 supra.

34. Stigler, Comment, 1964 J. Bus. $414,420$. 
economic model "assumes that the equilibrium price of investors is not affected by price movements or by the speculator's effects on such movements," Reference was again made to the substantial evidence indicating that the speculator could indeed aggravate price movements and thereby be destabilizing.

\section{HISTORY OF REGULATION}

\section{Early Specialist Rules}

The basic regulatory issues involving the specialist were delineated in the House Report accompanying the progenitor of the 1934 Act:

The importance of the actual workings of the exchanges themselves . . . should not be exaggerated. The stronger and more subtle economic forces affecting speculation come from without the exchanges. But as this speculation converges upon the exchanges, the control of the exchange mechanism is a necessary part of any effective regulation. It is for that reason that the bill gives the ... [ [SEC] broad powers over the exchanges to insure their efficient and honest functioning. ... .

No issue has been more disputed than that centering about the functions of the specialist. There are many who believe that the exchange mechanism would function better without the specialist [and] that the work done by the specialist could be done more effectively by a clerk . . . clearing the orders in a purely mechanical way . . . [ [O]thers . . believe that a specialist should be obliged to act either as a dealer or as a broker and should not be permitted to combine the functions of dealer and broker. . . . It is generally admitted that there are serious abuses in connection with the work of specialists. . . [T] There are inherent difficulties in the situation where under normal circumstances the available orders are known to the specialist only-and perhaps his favored friends-and not to everyone dealing in the security involved. I nasmuch as the stock exchanges objected to the laying down of any statutory rule governing specialists, their suggestion has been adopted of giving the Commission effective power to control the activities of specialists and to experiment with various devices of control. ${ }^{37}$

Section 11(b) of the 1934 Act contains the governing provisions for specialists subject to that Act. ${ }^{33}$

\footnotetext{
35. This was the Telser model which, according to Stigler, has as one of its components the excess demand of the speculators. Telser, $A$ Theory of Speculation Relating Profitability and Stability, 41 Rev. ECON. \& Stat. 295 (I959).

36. Friend \& Herman, Professor Stigler on Securities Regulation: A Further Comment, 1965 J. Bus. 106, 110.

37. H.R. Rep. No. 1383, 73d Cong., 2d Sess. 14-15 (1934).

38. 1934 Act \& 11 (b), 15 U.S.C. \& 78k(b) (1964), states:

When not in contravention of such rules and regulations as the Commission may prescribe as necessary or appropriate in the public interest or for the protection of
} 
In accordance with the $1934 \mathrm{Act}^{39}$ the Commission prepared a report to Congress in 1936 on the feasibility and advisability of the complete segregation of the functions of dealers and brokers. Concluding that such a segregation was not advisable at that time, this Segregation Report ${ }^{t 0}$ also described the initial steps taken to eliminate some of the undesirable consequences resulting from certain dealer and specialist activities on exchanges including the formulation a year earlier of sixteen proposed exchange rules ${ }^{11}$ which were implemented by all exchanges with minor modifications for the particular requirements of each exchange..$^{42}$ One rule was similar to section 11(b) and prohibited dealer trades by specialists unless "reasonably necessary to permit such specialist to maintain a fair and orderly market . . ."43 The purpose of this rule was described as follows:

investors, the rules of a national securities exchange may permit . . . (2) a member to be registered as a specialist. If under the rules and regulations of the Commission a specialist is permitted to act as a dealer, or is limited to acting as a dealer, sueh rules and regulations shall restrict his dealings so far as practicable to those reasonably necessary to permit him to maintain a fair and orderly market . . . . It shall be unlawful for a specialist or an official of the exchange to disclose information in regard to orders placed with such specialist which is not available to all members of the exchange, to any person other than an official of the exchange, a representative of the Commission, or a specialist who may be acting for such specialist; but the Commission shall have power to require disclosure to all members of the exchange of all orders placed with specialists, under such rules and regulations as the Commission may prescribe as necessary or appropriate in the public interest or for the protection of investors. It shall also be unlawful for a specialist acting as a broker to effect on the exchange any transaction except upon a market or limited price order.

39. "The Commission is directed to make a study of the feasibility and advisability of the complete segregation of the functions of dealer and brokcr, and to report the results of its study and its recommendations to the Congress on or before January 3, 1936." 1934 Act § 11(c) (formerly appearing as 15 U.S.C. $\S 78 \mathrm{k}(\mathrm{e})$; the section no longer appears but is noted following 15 U.S.C. § 78k(d) (1964)).

40. The Segregation Report was not directed solely at specialists, but at any member who acts as both broker and dealer. SPECIAL STUDY, pt. 2, at 48-50.

41. See Segregation Report 166-70.

Six of the proposed rules dealt specifically with specialists and provided that no member shall act as a specialist in any security unless registered as such by the exchange; that a speeialist's transactions should be limited to those reasonably necessary to permit the specialist to maintain a fair and orderly market; that the spccialist should not participate in any joint aecount except with a partner or another member; that the specialist should kcep a legible record of his orders for a period of at least 12 months; and that the specialist should not hold puts, calls, or other options in any sccurity in which he is registered as a specialist. 10 SEC ANN. REP. 42 (1944).

42. 10 SEC ANN. REP. 42 (1944).

43. SEGREGATION REPORT 169. The impact of this rule was questioned. "[W] hen the [NYSE] promulgated a rule in May, 1935, the wording of which simply parroted the Act's general 
It represents an attempt to eliminate the dealer activities of specialists except insofar as such activities allegedly perform a useful service to the market. In view of the specialist's fiduciary obligation to buyers and sellers whose orders he has accepted for execution; in view of his special knowledge and superior bargaining power in trading for his own account; in view of his peculiar opportunities and motivies for attracting public interest to the stock in which he specializes; and in view of the undesirable effect which his trading may exert upon the market; it was deemed essential by the Commission that the dealer functions of the specialist be subjected to stringent control. The rule was intended to allow him only sufficient latitude in his personal trading to enable him to maintain a fair and orderly market in the securities in which he is registered."

Finally, the Segregation Report recommended (i) increased emphasis on the observance of rules against trading by the specialist for his own account without affirmative justification and (ii) the development of appropriate restrictions on the specialist's trading with his "book."45

Although the need for rules to restrict unneeessary specialist dealer activities was emphasized, imposition of an affirmative obligation to maintain a fair and orderly market was not recommended. ${ }^{46}$ However, the Report recognized that specialists voluntarily assume this latter obligation as "a matter of business principle" since the specialist, by virtue of his combined broker and dealer functions and his commission business, has an important incentive to maintain a stable and orderly market.47

In 1937 the Commission endeavored to implement these two recommendations of the Segregation Report in the form of an

instructions, no real progress was made toward the regulation of specialists' trading." VERNON 71.

44. Segregation Report 63 (emphasis added). At the time of the Report the SEC had not had sufficient time to ascertain the effectiveness of these rules due to thcir evolutionary character. Id. at 64 .

45. Id. at 111 . In connection with the second point the Report suggested three prohibitions: a restriction upon dealings with the book which have the effect of widening the quoted market; a prohibition against dealings with the book which result in the establishment of a new high or low price during the course of a trading day; and a prohibition against taking all the stock offered or supplying all the stock bid for on his book at a particular price level, commonly known as "cleaning up the book." Id. at n.4.

46. "The specialist is under no affirmative obligation to maintain a fair and orderly market in the securities in which he specializes." Id. at 40.

47. Id. at 40-41. At the time of the Segregation Report specialists competed, creating a particular incentive to specialists to voluntarily make an orderly market since, as the Report believed, commission brokers would prefer to send their brokerage orders to the specialist who made the best market. As indicated in note 11 supra, NYSE and Amex specialists no longer compete, and this particular incentive has disappeared. However, the competition of the third market and regional exchanges may create a similar inducement. 
"interpretation" of the uniform specialist rule ${ }^{48}$ adopted in 1935 by all exchanges having a specialist system. ${ }^{49}$ The importance of the interpretation, commonly called the Saperstein Interpretation, ${ }^{50}$ warrants a brief summary. Compliance with the rule prohibiting a specialist from acting as dealer except to maintain a fair and orderly market was not to be evidenced by proof that a specialist dealer trade "had no undesirable effect or even no discernible effect, upon the market." "51 Rather, each transaction must be reasonably necessary to maintain a fair and orderly market. The "negative" test to be used in judging a lack of reasonable necessity is violated when the transaction "is not reasonably calculated to contribute to the maintenance of price continuity ... [and to the] minimizing of the effects of temporary disparity between supply and demand." ${ }^{152}$ In addition, the transaction must be considered in relation to the "immediate condition of the market" and "the specialist's book."

Finally, the adequacy of the specialist's position in relation to the "reasonably anticipated needs of the market" 54 may be a consideration in particular instances. The need to lessen "temporary disparity between supply and demand" and the reference to "immediate condition of the market" emphasize that the specialist acting as a dealer is responsible only for short run market stability or orderliness rather than intermediate or long term price trends or volume. The adequacy of his position to the "reasonably anticipated needs of the market" refers to the specialist's right to buy or sell in anticipation of future price trends. This permits him to build up a long position by trading in anticipation of a market rise and concomitant increase in the number of buyers. As the market subsequently rose the specialist would supply stock purchased earlier. If he refused to do this, his long position could not be justified under the Saperstein doctrine. Thus, the negative restriction can imply an affirmative obligation to deal, creating a need for the specialist to enter the market as seller rather than to refrain from dealing.

The Saperstein Interpretation further specified certain types of transactions commonly considered unjustifiable including: a purchase

\footnotetext{
48. See text accompanying note 43 supra.

49. SEC Securities Exchange Act Release No. 1117 (Mar. 30, 1937).

50. David Saperstein was the Director of the Commission's Trading and Exchange Division, now the Division of Trading and Markets.

51. Release No. 1117, supra note 53, at 2.

52. Id.

53. Id.

54. Id.
} 
above the last sale price; the purchase of all or substantially all the stock offered on the book at the last sale price; and the supplying of all or substantially all the stock bid for on the book at the last sale price. 55

The Saperstein Interpretation, the last formal Commission pronouncement on permissible dealer activities of specialists until the Amex Report of $1962,{ }^{56}$ evidently had little effect. In 1941 "statistical evidence [failed], to show any substantial change in the trading habits of the specialist after the Commission's interpretation was made public."

In 1938 the Commission and the NYSE commenced an investigation of the financial status of Exchange specialists to determine whether specialists were financially able to maintain a fair and orderly market and whether an Exchange rule was necessary to require that specialists have adequate capital.58 In 1939, the NYSE minimum capital requirements were set at $\$ 10,000$ or the market value of 100 shares of each specialty stock, whichever figure was higher. ${ }^{50}$ This development implicitly recognized the specialist's affirmative obligation to enter the market. If the specialist's only obligation was the negative one described in the Saperstein Interpretation and the Segregation Report-no affirmative requirement to act as dealer but any such action must be in a prescribed manner-arguably no mandate of a special minimum capital requirement would be needed. The Exchange, by enacting a minimum capital requirement under informal Commission prodding, seemed to be requiring the specialist to affirmatively deal to make a fair and orderly market, at least to the extent of his minimum capital. ${ }^{60}$

\section{Commission Rules Regulating Specialists}

\section{Commission Rule $11 b-1$}

Commission rule $11 \mathrm{~b}-1$ governing specialists, implemented in January, 1965, is principally based on section 11(b) of the 1934 Act which states in part that

[w] hen not in contravention of such rules and regulations as the Commission

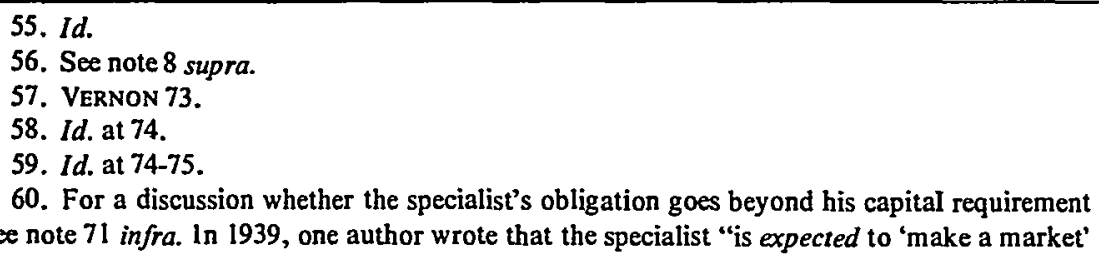


may prescribe . . . the rules of a national securities exchange may permit . . . a member to be registered as a specialist. If . . . a specialist is permitted to act as a dealer . . . such rules and regulations [of the Commission] shall restrict his dealings so far as practicable to those reasonably necessary to permit him to maintain a fair and orderly market . . . ."

The Commission's specialist rule provides that national securities exchanges may permit a member to register as a specialist and to act as both dealer and broker if the applicable exchange rules meet certain criteria. The NYSE and Amex had permitted dual broker-dealer functions even before the enactment of the 1934 Act, but the specialist rule first embodied the Commission's formal acknowledgment of the combined broker-dealer function performed by specialists.

Rule $1 \mathrm{lb}-\mathrm{I}$ provides that the rules of the exchanges must include five basic provisions:

1. Adequate minimum capital requirements.

2. Affirmative requirements that a specialist engage in dealings for his own account to assist in the maintenance, insofar as practicable, of a fair and orderly market. This is often described as the "affirmative" obligation of the specialist to deal. "Substantial" or "continued" failure by a specialist to engage in such a course of dealings should result in the suspension or cancellation by the exchange of the specialist's registration in one or more of his specialty stocks.

3. Restrictions on his dealings so far as practicable to those reasonably necessary to maintain a fair and orderly market. This is often described as the "negative" restriction on specialists and incorpórates the Saperstein Interpretation.

4. Provisions defining the responsibilities of specialists acting as brokers.

5. Procedures to provide for effective and systematic surveillance of specialists. ${ }^{62}$

The rule also establishes a procedure for Commission review and, if necessary, disapproval of new exchange rules relating to specialists. ${ }^{63}$ The Commission is given power to order the exchange to

by putting in a bid and an offer whenever no bids or offers are made by other members at a reasonable "spread.' " C. HARDY, supra note 29, at 116 (emphasis added).

61. 15 U.S.C. $\$ 78 \mathrm{k}(\mathrm{b})$ (1964). The Special Study had recommended that a Commission rule be adopted under section 11 of the 1934 Act to enable the Commission to more readily exercise regulatory control over the specialist. Special Study, pt. 2, at 168. The full tcxt of section 11 (b) is reproduced at note 38 supra.

62. 17 C.F.R. $\$ \S 240.11 b-1(a)(2)(i)-(v)(1970)$.

63. The Commission has 30 days after the filing of a proposed rule to notify the exchange of its intention to determine whether the proposed rule should be disapproved. The exchange has 60 
cancel or suspend a specialist's registration in one or more of his specialty stocks upon finding that the specialist has made dealer trades which are not part of a course of dealings reasonably necessary to maintain a fair and orderly market, not effected in a manner consistent with the rules adopted by such exchange, and thus a violation of his "negative" obligation. However, if the exchange has itself suspended or cancelled a specialist's registration, no sanction shall be imposed by the Commission under this rule unless the Commission finds "substantial" or "continued" misconduct by the specialist. 64

Finally, the Release promulgating the new rule provided that only the New York and American Stock Exchanges are to be subject to the rule's requirements. The exemption of all other exchanges was based upon their limited volume of transactions and "the fact that the Commission had not made any studies of the structure of the regional exchange specialist system."

days after such notification to present evidence or arguments in support of its position. After consideration of all relevant material, the Commission may disapprove the proposed change or addition in the rules. Id. $\S 240.11 \mathrm{~b}-\mathrm{l}(\mathrm{a})(3)$. This procedure should be contrasted with that of rule 17a-8 and section 19(b) of the 1934 Act. Under rule 17a-8 each national securities exchange must file any proposed amendment to its rules not less than 3 wceks before the amendment is to take effect unless it is an emergency amendment. However, the Commission is not given any power under this section to change the amendment. The rule itself states that notwithstanding a failure on the part of the exchange to submit the amendment to the SEC, the validity of the change will not be affected. $I d$. $\S 240.17 \mathrm{a}-8$ (d). Rule $17 \mathrm{a}-8$ apparently applies to specialists' rules also.

Section 19(b), 15 U.S.C. $\$ 78 \mathrm{~s}$ (b) (1964), in contrast to rule 17a-8, gives the Commission the power in 12 designated areas to make specified changes or additions in an exchange's rules and practices after an appropriate request and hearing. However, since the specialist is not mentioned within these 12 categories, arguably section 19(b) was not meant to apply, especially since the specialist is covered under another portion of the Act-section 11(b). Because of the important role of the specialist and the broad power that is in section 19(b)-section 19(b)(1) gives the Commission power to safeguard the financial responsibility of members; section 19(b)(3) refers to listing of securities; section 19(b)(5) refers to manner, method, and place of soliciting business; and section $19(\mathrm{~b})(13)$ refers to "similar matters"-it seems more likely that section 19(b) is applicable to the specialist. However, although section 11(b) refers to both. specialist and odd-lot dealers, section 19(b) refers only to odd-lot dealers. See 2 L. Loss, SeCurities Regulations 3219 (1969 Supp.).

Rule $1 \mathrm{lb}-1$ procedure does not permit the Commission to require a change in exchange rules on its own initiative. However, it would appear that the Commission has the power from the first sentence of section 11(b) of the 1934 Act to require broad changes in such exchange rules or to pass additional Commission rules regarding the specialist as may be "necessary or appropriate in the public interest or for the protection of investors." Thus, even if section 19(b) had limited application to specialists, no void in Commission power would appear to exist in this area.

64. Rule 11b-1(b), 17 C.F.R. § 240.1 lb-1(b) (1970).

65. SEC Securities Exchange Act Release No. 7465 at 3 (Nov. 23, 1964). Previous to this exemption all exchanges with a specialist system were subject to the Saperstein Interpretation. 
Original drafts of the Commission rule sent to the New York and - American Stock Exchanges apparently imposed an affirmative obligation on the specialist to deal where necessary to maintain an orderly market..$^{66}$ However, the final version provides that the affirmative obligation be included in an exchange rule. ${ }^{67}$ The Special Study had recommended that a Commission rule be adopted under section 11(b) to state an affirmative obligation to participate but recognized that section 11 has no explicit provision requiring specialists to participate in the market as principal. ${ }^{68}$ Possibly the uncertainty concerning Commission authority ${ }^{69}$ and fear of increased risk of private law suits against both the specialists and the exchange based upon such a Commission rule ${ }^{70}$ led to the adoption of the affirmative obligation to deal provision as an exchange rather than a Commission rule.

The exchange rule must also require that the specialist engage in a "course of dealings" to "assist" in the maintenance of a fair and orderly market "so far as practicable," indicating that the specialist's activities are not to be judged on the basis of one transaction and that the amount of stablizing purchases or sales he must accomplish is within reasonable limits. The measure of his affirmative obligation to help maintain a fair and orderly market may be related to the minimum amount of capital required to be maintained by the exchange rule.1

The original draft of the rule sent to the NYSE and Amex

\footnotetext{
After promulgation of rule $1 \mathrm{lb}-\mathrm{I}$, however, the regional exchanges are exempted from the negative requirement of the Interpretation and the new affirmative obligation of the rule. Regional exchanges may elect to pass their own rules to provide for such restrictions and obligations. However, to the extent that such regional exchanges have rules and settled practices governing the specialist, they are obligated under the self-regulatory provisions of sections 6 and 19 of the 1934 Act to enforce them. Additional consideration of regional exchanges is bey ond the scope of this paper.

66. Hearings Before a Subcomm, of the House Comm. on Interstate and Foreign Commerce, 88th Cong., 1st \& 2d Sess. 1252-53 (1963-64). These hearings present an excellent analysis of the specialist system under stress resulting from the Kennedy assassination. Included in the hearings - is a Commission staff report on trading on both the day of the assassination and the next day in which the market was open.

67. Sce text accompanying note 62 supra.

68. Compare SPECIAL STUdy, pt. 2, at 168 with id. at 89.

69. For a discussion of Commission authority in this area see note 63 supra.

70. For a discussion of potential civil liability for violation of an exc.1ange rule, see text accompanying notes $135-45$ infra.

.71. Although there is general agreement that a specialist has no obligation to bankrupt himself in a steeply rising or falling market, inflexible determination of the amount of his obligation by his capital requirement is arguably incorrect. In certain instances his obligation may be considerably more than this amount depending on the precise facts of a given case.
} 
apparently intended to directly impose the negative restrictions on specialist dealing, ${ }^{72}$ but the final rule, perhaps to lessen the fear of civil liability, required this restriction to be incorporated in the rules of the exchanges rather than as a direct rule of the Commission. ${ }^{73} \mathrm{~A}$ notable difference exists, however, in the treatment of failure to meet the affirmative rather than the negative obligation: As noted above, the Commission has the power under the rule to order the exchange to suspend the specialist in the latter case. In the former case the Commission has no such explicit authority; rule $11 \mathrm{~b}-1$ merely requires that exchange rules provide for the disciplining of a specialist who violates his affirmative obligations. In the case of an exchange neglecting to suspend or cancel the registration of a specialist for failing to engage affirmatively in a course of dealings to assist in the maintenance of a fair and orderly market, the Commission's remedy, unless it were to promulgate a new rule under section 11(b), would appear to be under section 19(a)(1) of the 1934 Act which permits the suspension or withdrawal of the registration of a national securities exchange upon the finding that the exchange has violated the Act or any rule thereunder. ${ }^{i 4}$ This is obviously a drastic and radical measure.

Prior to rule $11 \mathrm{~b}-1$ there was no formal Commission rule on specialists. Arguably, however, section 11(b) was self-executing, and the Saperstein 1nterpretation's negative obligation was in effect as a Commission rule. Section 11(b) provides that "[i]f under the rules and regulations of the Commission a specialist is permitted to act as a dealer. . . such rules and regulations shall restrict his dealings so far as practicable to those reasonably necessary to permit him to maintain a fair and orderly market ... ."75 Since the Commission in fact always permitted specialists to act as dealers from 1934 to the date of rule $11 \mathrm{~b}-1$, a possible inference is that specialists acting as dealers were required to comply with the negative restrictions of section 11(b). Accordingly, section 19(a)(3), providing that the Commission may suspend or expel from a national securities exchange any member thereof when the Commission finds that he has violated any provision of or rule under the 1934 Act, may have been applicable up to the passage of rule $11 \mathrm{~b}-1$. However, since the

72. Hearings, supra note 66 , at 1252.

73. This approach requires an interpretation that section $11(b)$ 's mandate that the Commission establish rules to restrict specialist dealings is satisfied by the promulgation of exchange rules with the same prohibitions.

74. 15 U.S.C. $\$ 78 \mathrm{~s}(\mathrm{a})(1)$ (1964).

75. Id. $\S 78 \mathrm{k}(\mathrm{b})$ (emphasis added). 
Commission did not adopt a rule until $11 \mathrm{~b}-1$ was promulgated in 1965, arguably section 11 (b) was not operative in this regard absent such a formal rule.

\section{Other Regulatory Provisions}

The specialist is, of course, also liable for any violations of other federal securities laws including 1934 Act sections 9(a) and 10(b) ${ }^{76}$ and rules $10 \mathrm{~b}-5^{77}$ and $10 \mathrm{~b}-6^{78}$ thereunder which refer to manipulation. The Commission has stated that "Section 11 of the Exchange Act grants to the Commission broad and direct rulemaking power over the activities of specialists and adoption of proposed Rule $11 \mathrm{~b}-1$ would in no way foreclose the Commission from exercising its residual power of direct regulation." ${ }^{79}$ In United States $v . R e^{80}$ the court considered whether the defendant Amex specialists were acting "in the legitimate role of specialists, not as market manipulators." defendants' contention that the anti-manipulative provisions "are irreconcilably inconsistent with the legitimate duty of the specialist," the court concluded that "[i]nherent in the jury's verdict of guilty . . . was the determination that the Res were not performing the function of specialists in their dealings . . . ."82

A specialist may possibly violate his duty to create a "fair" market without violating the anti-manipulative sections of the federal securities laws. The term "fair" would thereby have ethical connotations somewhat similar to NYSE rule 401 which places a standard of good business conduct upon NYSE members. ${ }^{83}$ Since "fair" is part of rule $11 \mathrm{~b}-1$ of the 1934 Act, this ethical connotation is incorporated in federal as well as exchange standards concerning spccialists' activities. The Commission has stated that the specialist

76. Id. $\S \S 78 \mathrm{i}(\mathrm{a}) \& 78 \mathrm{j}(\mathrm{b})$.

77. 17 C.F.R. § $240.10 \mathrm{~b}-5(1970)$.

78. Id. $\S 240.10 \mathrm{~b}-6$. In a recent administrative proceeding, Jaffee \& Co., SEC Securitics Exchange Act Release No. 8866, April 20, 1970, the Commission in discussing rule 10b.6 with regard to a market maker stated: "A specialist, no less than an over-the-counter markct maker, is subject to the prohibitions of the Rule if he is a participant in a distribution [other than one exempted under 10b-6(a)(10)1." Id. at 6 n.12a. Query can a specialist comply with his duty to maintain a fair and orderly market and, at the same time, violate rule 10b-6? Compare id. with id. at 13 (Commissioner Smith dissenting).

79. SEC Securities Exchange Act Release No. 7432 at 8 n.2 (Sept. 24, 1964).

80. 336 F.2d 306 (2d Cir. 1964).

81. Id. at 314 .

82. Id. at 315 .

83. See note 125 infra and accompanying text. 
also functions as a broker executing orders entrusted to him by other brokers on behalf of their customers in the securities in which he specializes. Thus, he is in a position of trust and confidence with his customers and obligated within the terms of his agency to the strict standards of loyalty, disclosure and fair dealing required of fiduciaries. ${ }^{84}$

It is arguable that a violation of a duty to keep a "fair" market could also lead to possible civil liability ${ }^{85}$

\section{Exchange Rules Regulating Specialists}

The NYSE adopted a number of significant changes in its specialist rules as a result of the Commission's promulgation of rule $11 \mathrm{~b}-1$. The current framework of rules is described in this section with reference to any changes made as a result of rule $1 \mathrm{lb}-1$ and the recommendations of the Special Study. ${ }^{86}$ The central provisions governing specialists are set forth in NYSE rule 104 and the supplementary material thereto.$^{87}$

The first paragraph of rule 104 is almost identical to the rule in effect at the time of the Saperstein Interpretation in 1937. The initial

84. Re, Re and Sagarese, SEC Securities Exchange Act Release No. 6900 (Sept. 21, 1962).

85. See text accompanying notes $135-48$ infra.

86. Similar changes were adopted by the Amex. This discussion relates principally to NYSE rules with appropriate reference to Amex rules.

87. Relevant portions of NYSE rule 104 are as follows:

Rule 104. No specialist shall effect on the Exchange purchases or sales of any security in which such specialist is registered, for any account in which he, his member organization or any participant therein is directly or indirectly interested, unless such dealings are reasonably neeessary to permit such specialist to maintain a fair and orderly market, or to act as an odd-lot dealer in such security.

.10 Regular specialists.-[Registration required].

The function of a . . . regular specialist . . . includes . . . the maintenance, in so far as reasonably practicable, of a fair and orderly market on the Exchange in the stocks in which he is so acting. ...

(1) The maintenance of a fair and orderly market implies the maintenance of price continuity with reasonable depth and the minimizing of the effects of temporary disparity between supply and demand.

(2) ... [1]t is commonly desirable that a member acting as specialist engage to a reasonable degree under existing circumstances in dealings for his own account when lack of price continuity, lack of depth, or disparity between supply and demand exists or is reasonably to be anticipated.

(3) Transactions on the Exchange for his own account effected by a member acting as specialist must constitute a course of dealings reasonably calculated to contribute to the maintenance of price continuity with reasonable depth, and to the minimizing of the effects of temporary disparity between supply and demand, immediate or reasonably to be anticipated. Transactions not part of such a course of dealings are not to be effected. 
provisions of rule 104.10 setting forth the specialist's affirmative obligation generally were, with certain differences, effective for many years prior to the Special Study and are now required to be included pursuant to SEC rule 11 b-1(a)(2)(ii). Moreover, as a result of recommendations of the Special Study, the phrases related to "depth" were added. In this regard, the Commission stated that

a related finding [of the Study] was [that] there was too much emphasis upon transaction by transaction price continuity, as distinguished from the concept of depth, i.e., the ability of the market to supply and absorb reasonable quantities of stock before significant price changes occur . . . . [The] problem has been met by an amendment to existing rules which specifically adds the concept of market depth to the obligations of specialists as dealers..$^{83}$

In announcing this amendment, the NYSE asserted that the term "reasonable" in rule $104.10(1)(2)$ and (3) "implies that the appropriate degree of participation will vary with conditions in each stock-price range, volume, etc.-and with over-all market conditions." $" 89$

The general statements in paragraphs 1,2 , and 3 of rule 104.10 provide only the most general guidelines. For example, no one expects

(4) A specialist's quotation . . . will bear a proper relation to preceding transactions and anticipated succeeding transactions.

(5) Transactions . . . are to be effected in a reasonable and orderly manner in relation to the condition of the general market, the market in the particular stock and the adequacy of the specialist's position to the immediate and reasonably anticipated needs of the market. The following types of transactions to establish or increase a position are not to be effected except when they are reasonably necessary to render the specialist's position adequate to such needs:

(A) a purchase at a price above the last sale in the same session;

(B) the purchase of all or substantially all the stock offered on the book at a price equal to the last sale, when the stock so offered represents all or substantially all the stock offered in the market; and when a substantial amount of a stock is offered at a price egual to the last sale price the purchase of more than $50 \%$ of all the stock offered;

(C) the supplying of all or substantially all the stock bid for on the book at a price equal to the last sale, when the stock so bid for represents all or substantially all the stock bid for in the market; and when a substantial amount of a stock is bid for at a price equal to the last sale price, the supplying of more than $50 \%$ of all the stock bid for; and

(D) failing to reoffer or rebid where necessary after effecting transactions described in $(A),(B)$ and $(C)$ above.

Transactions of these types may, nevertheless, be effeeted with the approval of a Floor official or in less active markets where they are an essential part of a proper course of dealings and where the amount of stock involved and the price change, if any, are normal in relation to the market.

....

The portions in italics were added in 1965. The equivalent Amex provision is Amex rule 170.

88. Release No. 7432, supra note 79, at 4-5.

89. NYSE Memorandum to Members and Allied Members 8 (Sept. 24, 1964). 
a specialist to become insolvent to stem a long-run market downswing. On the other hand, the specialist is required to buy within reasonable limits to meet temporary disparities in public supply and demand. The difficulty arises in actually measuring the limit and scope of his obligation. Suppose that the exchange delays the opening of a stock due to a sudden influx of public sellers. Assume further that (a) the specialist must expend $\$ 50,000$ of his own capital to meet the sell orders, without a significant drop in price; or (b) the specialist would have to expend $\$ 6$ million to meet the sell orders at a price which is reasonably close to the last sale. What is the specialist's obligation in each case? What standards should the exchange use in measuring the specialist's precise dollar obligation under rule 104? A paradox may exist: If the specialist has a legal obligation to buy or sell only in cases of relatively non-serious imbalances, then the economic value of the specialist is somewhat lessened. In such nonserious cases, the public imbalance of buy and sell orders is relatively small and price gyrations may not be great even without the specialist. On the other hand, imposition of liability on the specialist to stem great imbalances of demand would call for greater capital resources than most specialists can command by themselves.90

Paragraphs (5)(B) and (C) of rule 104.10 , prohibiting what is commonly called "cleaning up the book," were amended in 1965 to include a specific statement regarding the 50 percent limitation on specialists' transactions in connection with establishing or increasing positions in specialty stocks. The first clause of paragraph (5)(B) prohibits the purchase of all or substantially all the stock offered on the book at a price equal to the last sale when the stock so offered represents all or substantially all of the stock offered in the market. Hence, if 2,000 shares were offered on the book and 4,000 offered in the crowd, this clause standing alone would appear to permit the specialist to buy the full 2,000 on the book for his own account, plus perhaps all or part of the stock offered in the market. However, the second clause limits the specialist to 50 percent of all the stock offered, subject to the general restrictions against unnecessary dealing. These prohibitions against cleaning up the book are refinements of prohibitions dating back to the Saperstein

90. Recently, there has been a development to have certain financially strong members of exchanges affiliate with specialist units. See the text accompanying note 153 infra. 
Interpretation and apply to transactions which "establish" or "increase" a position-Iong purchases or short sales.

Paragraph (6), added in 1965, provides limitations on the specialist's transactions in connection with liquidating or decreasing a position and applies to long sales and purchases to cover a short position. Without prior approval of a Floor Official, the specialist must avoid liquidation of all or substantially all of a position by selling stock at prices below the last different price or by purchasing stock at prices above the last different price. The specialist must also maintain a fair and orderly market during liquidation. The Commission announced that these changes were made in response to the Special Study's conclusion that NYSE rules did not adequately "inhibit potential disruptive market effects that could follow from an extensive liquidation or reduction of a specialist's position." 11

Rule 104 was also modified in 1965 to state that a specialist should avoid participating as a dealer in opening or reopening a stock in such a manner as to upset the public balance of supply and demand, unless the conditions of the general market or the specialist's position make it advisable to do so in light of the reasonably anticipated needs of the market. ${ }^{92}$ This change complied with the Special Study recommendation that specialists be prohibited from changing prices at openings against the direction indicated by public supply and demand..$^{93}$

NYSE rule 103 contains the requirement that no individual may act as a specialist without being registered with the Exchange.4 In 1965, the rule was modified to provide that if the Exchange finds a

91. Release No. 7432, supra note 79, at 4. The equivalent Amex prohibitions on liquidations and cleaning up the book appear in Commentary .01 and .02 to Amex rule 170 .

92. NYSE rule 104.11. A similar Amex rule appears as Commentary 04 to Amex rule 170. The "opening" function of the specialist was considered to be very important by the Special Study. Special Study, pt. 2, at 137.

93. SPECIAL Study, pt. 2, at 168. The supplemcntary material to NYSE rule 115 contains additional regulations on orders at openings. Rule $115.20(2)$ provides that in arranging an opening a specialist is required to assure that each market order he holds participates in the opening transaction. However, if such a market order is for more than 100 shares, the size of the transaction 'which establishes the opening or rcopcning price fixcs the amount that the market order is entitled to participate in at the opening or reopening. This limit would appcar to be subject to the specialist's affirmative obligation to deal under Commission rule $11 \mathrm{~b}-1$ and NYSE rule 104. Rule 115.20(2) further provides that market orders have preccdence over limited orders at the opening or reopening. Limit price orders to buy at a highcr price than that at which the security is to be opened are treated as market orders. Limit price orders to scll at lower prices than the opening price are treated as market orders. NYSE rule $115.20(2)$.

94. See note 41 supra. 
substantial or continued failure to engage in a course of dealings directed toward the maintenance of a fair and orderly market, the specialist's registration in one or more of his specialty stocks shall be subject to suspension or cancellation by the Exchange. This amendment had the effect of implementing paragraph (a)(2)(ii) of SEC rule $11 \mathrm{~b}-1$.

Capital requirements of NYSE specialists require each unit to have the ability to assume a position of 20 trading units $-2,000$ shares in a 100 share unit stock - in each common stock in which it is registered. ${ }^{55}$ The requirement was 400 shares prior to 1964 and was raised to 1,200 shares by the Exchange concurrently with the enactment of rule $11 \mathrm{~b}-1.96$ This capital requirement is not to be confused with a net capital requirement, since the specialist himself is not required to have net capital sufficient to assume a position of 20 trading units. The specialist may fulfill this capital requirement either with his own funds or by borrowing from a bank or another member organization. ${ }^{97}$ The NYSE also adopted a rule in 1965 requiring that it be informed immediately by telephone of any intention to terminate

95. NYSE rule 104.20. The Amex requirement is 20 trading units or $\$ 100,000$, whichever is greater, and was changed recently from ten trading units of $\$ 50,000$. Amex rule 171 .

96. Release No. 7432, supra note 79, at 3. The Special Study had recommended this change. SPECIAL STUdY, pt. 2, at 168.

97. The specialist is exempt from the initial margin requirements imposed by the Federal Reserve System under its regulations T and U. 12 C.F.R. $\S \S 220.106 \& 221.102$ (1970). The NYSE specialist is also exempt from the net capital requirements of NYSE rule 325 as long as he does not engage in public business. However, the maintenance margin requirements of NYSE rule $\mathbf{4 3 1}$ are to some extent applicable in that an amount borrowed from a clearing agent in excess of the general maintenance margin rule will be a debit to the clearing agent in the computation of his net capital. NYSE rule 431 (c)(6).

1934 Act rule 15c3-1 requires that in most eases all brokers and dealers maintain a minimum net capital of $\$ 5,000$. 17 C.F.R. $\S 240.15 c 3-1$ (1970). Exchanges with a capital requirement more stringent than that of $15 \mathrm{c} 3-1$ are exempt. NYSE rule 325 requires that most members have a net capital position of $\$ 50,000$. Amex rule 446 is similar. However, both exchanges currently exempt specialists who do not do a public business from the requirements of their net capital rules, and presumably they are also exempt from 1934 Act rule 15c3-1.

The relevance of not having a net capital rule applicable to the specialist lies in the fact that his "buying powcr" will be increased. If the speeialist were obliged to maintain a minimum net capital of $\$ 50,000$, each dollar in excess of minimum net capital that the specialist receives will enable him to buy 3-1/3 times that ambunt in securities since 30 percent of the market value of a security is deducted in ascertaining its value for net eapital purposes. This percentage is called the "haircut." For example, if a specialist firm had $\$ 50,001$ in net eapital, its security position could be improved by a maximum of $\$ 3.33$ by using the extra $\$ 1$ and borrowing $\$ 2.33$. After deducting the $\$ 2.33$ increase in liabilities and a 30 percent "haircut," its net capital would decrease $\$ 1$. Thus it would now have $\$ 50,000$ in net capital. If there were no net capital requirements the purchasing power of that same dollar would be four times its value due to the present 25 pcrcent maintenance margin standard. 
or change existing financial arrangements or to issue margin calls to specialists. Both the Amex and NYSE agreed to inform the Commission immediately by telephone if a specialist would apparently not be able to meet promptly a margin call or to continue in business because of his inability to obtain new financing. ${ }^{08}$ These provisions enable the exchanges to enforce the restrictions on specialist' liquidations where margin calls might cause the specialist to start liquidating his position and in general to police the financial responsibility of specialists.

A number of rules deal with the agency or brokerage functions of specialists. The Special Study recommended that the NYSE and Amex should adopt rules prohibiting specialists from servicing the accounts of their own public customers ${ }^{99}$ to eliminate the potential for discrimination. ${ }^{100}$ The Amex argued that the effect of this recommendation would be to diminish the capital resources of many specialists, since firms forced to split into two or more firms-one handling public customers, the other acting solely as specialist-would be smaller and weaker. The Amex also argued that such a ban would prevent it from interesting firms now engaged in a public business in specializing. ${ }^{01}$ The NYSE, asserting that specialists had not given preferential treatment to their own public customers, contended that it would be undesirable to have a "blanket prohibition against specialists' handling public accounts." 102 As a compromise, the NYSE adopted a rule prohibiting specialists from accepting an order for his specialty stock directly from the issuer, any officer, director, or 10 percent stockholder of the issuer, pension or profitsharing funds, or institutions such as banks, insurance companies, and mutual funds. ${ }^{103}$ Supplementary material to the rule provides that

98. Release No. 7432, supra note 79, at 7; NYSE rule 104.30; Amex rule 171.01. This amendment implemented the essence of the Special Study recommendation. SPECIAL STUDY, pt. 2 , at 170 .

99. The Special Study recommendation on this subject stated: "To keep within as narrow limits as possible the conflicts of interest inherent in a specialist's combination of functions, NYSE and Amex specialists and their firms should be prohibited from servicing the accounts of public customers, or receiving commissions on such accounts 'introduced' by them at other firms." Special Study, pt. 2, at 170.

100. Id. at 154-57.

101. Hearings, supra note 66 , at $444-45$.

102. NYSE Memorandum, supra note 89 , at 16.

103. NYSE rule 113 also prohibits the identification of an order in a specialty stock with an account and provides for the reporting of specialty stock transactions made for accounts related to his member organization. 
it is contrary to good business practice for a specialist or his firm to "popularize" any security in which he is registered.

The Special Study has recommended that all securities owned by a specialist and in which he is registered should be kept in one trading account rather than segregated in long-term investment accounts for tax or other purposes. ${ }^{104}$ The existence of such accounts was considered inconsistent with the Saperstein Interpretation in that the specialist was made a long-term investor regardless of his obligation to buy and sell stock only when reasonably necessary to maintain a fair and orderly market. ${ }^{105}$ The final determination was that under certain circumstances a specialist may have an investment account. NYSE rule $104.12^{106}$ provides in part that purchases for the investment account must be reasonably necessary to permit the maintenance of a fair and orderly market. Moreover, no stock which was purchased on destabilizing ticks may be placed in the account. These requirements are designed to reconcile the existence of the investment account with the negative and affirmative obligations of the specialist under NYSE rule 104 and Commission rule $11 \mathrm{~b}-1$. In addition, the specialist's income data reported to the NYSE must "reflect, by speciality stock, any gain or loss occurring within an investment account."'107

The practice of stopping stock was criticized by the Special Study. ${ }^{108}$ If a floor broker is dissatisfied with the then quoted market, he may utilize this device by asking the specialist for a "stop." If granted, the broker is assured a price for his customer no worse than the current market. If a better price is available at a later time, the order will be executed, and the "stop" is null and void. The Special Study noted that usually the "stop" would be filled from the book

The similar Amex provision is rule 190. Recently both the NYSE and Amex have discussed arrangements with large brokerage houses which would enable these firms to affiliate with the specialist to help the latter's capital position. Discussions concerning changing rules which might prohibit these potential affiliates from doing certain types of public business have also been reported. The NYSE has formed a special committee to study the matter. Washington Post, Jan. 9, 1970, § D, at 7, col. 1.

104. Special. Study, pt. 2, at 169. The Internal Revenue Code provides that a dealer in securities may receive capital gains treatment for the sale of a security if within $\mathbf{3 0}$ days of purchase the security was identified as held for investment and not after this 30 days at any time held primarily for sale to customers. 1NT. REV. CODE of $1954, \S 1236$.

105. Special Study, pt. 2, at 133-35.

106. A similar rule was adopted by the Amex. Commentary .07 to Amex rule 170 .

107. NYSE rule 104.50.

108. Speclal. Study, pt. 2, at 169. 
and only rarely by the specialist as dealer. ${ }^{109}$ In 1965 NYSE rule 116 was modified to provide that with certain limited exceptions, a specialist may not stop stock against the book or for his own account if he holds an order capable of execution at the "stopped" price. In those limited cases when a stop may be granted, the guarantee must result in narrowing quotations on the exchanges. ${ }^{110}$ The Special Study noted that the NYSE permitted "stopped" stock transactions to be omitted from the tape; ;11 rule $126^{112}$ was amended to eliminate this practice.

Several other exchange rules directly regulate the dealings of the specialist. In certain circumstances he is permitted to execute "off the floor" transactions for his own account without satisfying orders from his book, ${ }^{113}$ but he may not accept "not held" orders which permit discretion as to time and price of execution. ${ }^{114}$ Dealings to adjust LlFO inventory in a specialty stock are prohibited. ${ }^{115}$ Also a specialist may not pay a better price for a block for his own account than his brokerage customers pay for other pieces of the same block. ${ }^{116}$ In successive dealer transactions with his customers' orders a

109. Id. at 150-54. The danger with "stopped" stock was that the customer's order on the book allocated to the "stop" would not receive an execution if the order with the benefit of the stop received a better price later during the day. Thus the allocated stock might fail to obtain a timely execution, especially if the market subsequently moved away from its limit price.

110. In announcing this rule change the NYSE stated that "stopping" stock permits the investor to have his order executed at a better price than othenwise. NYSE Memorandum, supra note 89 , at 12 .

111. The Special Study recommendation on the subject provides: "The present policy of the NYSE which permits executions resulting from stops to be omitted from the tape should be changed by a rule requiring that every transaction taking place on the floor be reported on the tape. The policy requiring the selling broker to report transactions should be strictly enforced." SPEC1AL Study, pt. 2, at 169.

112. NYSE rule 126 Supplementary Material.

113. Prior approval of a Floor Governor is required. NYSE rule 107.

114. NYSE rules 123.20 and 123.44. "Not held" orders arc also prohibited by section 11(b) of the 1934 Act, 15 U.S.C. $\S 78 \mathrm{k}$ (b) (1964), which limits the specialist to accepting market or limit orders. The danger in these orders is that the great discretion given to specialists would permit them to mánipulate prices. There is no ban on members other than specialists in handling "not held" orders. The Special Study recommended that "[t]he existing ban against specialists" accepting 'not-held' orders should continue. If necessary, consideration should be given to increasing floor brokerage rates to compensate floor brokers adequately for their efforts in handling discretionary orders." SPECIAL STUDY, pt. 2, at 169.

115. NYSE rule 104.13 provides: "L1FO transactions.-A member acting as a specialist may not effect transactions for the purpose of adjusting a LIFO inventory in a stock in which he is so acting except as a part of a course of dealings reasonably neccssary to assist in the maintenance of a fair and orderly market." This was designed to prevent ycar-end purchases or sales for the purpose of obtaining tax advantages under the L1FO system of valuing inventory. Release No. 7432, supra note 79, at 5.

116. NYSE rule 104.10(7). 
specialist must charge all of them the best price which any of them receive. ${ }^{117}$ No member, including a specialist, may fill buy or sell orders accepted by his organization as principal, except under certain exceptions. ${ }^{118}$

There are also several additional general proscriptions on a specialist's conduct. He is prohibited from participating in "pool dealing" in his specialty stock ${ }^{119}$ and may not hold any interest in a joint account for specialty stock, except with another member organization. ${ }^{120}$ Proxy contest activity, directorships, and other business dealings with companies in whose stock he is registered are also forbidden. ${ }^{121}$ The specialist is subject to certain other rules of the exchange involving record keeping for "own account" transactions, ${ }^{122}$

117. NYSE rule 104.10(8).

118. This applies to all members; one requirement is that the member, including specialists, may buy the securities provided that he has offered the same on the Floor at a price which is at least an eighth higher than his bid. The converse must be done if he is selling to the customer's bid. NYSE rule 91 . In the case of specialists, additional requirements are added. NYSE rule 91.20 provides that "a specialist occasionally may effect a transaction as principal against an order which has been entered for an account carried by the specialist's organization . . . . The customer . . . should be contacted promptly . . . so that he may then accept or reject the transaction." (emphasis added). See also NYSE rule 113, note 103 supra.

119. NYSE rule 105.

120. NYSE rule 94. See note 41 supra. The Amex has a similar rule. Amex rule 175. The Amex recently studied investment partnerships or "hedge funds" and considered the participation of specialists in such partnerships. The American Stock Exchange stated:

The Exchange's survey noted that a few member organizations represented by a limited partner in an investment partnership have an affiliation with a specialist unit. The attention of such organizations is directed to Rule 175(b), which prohibits any specialist, or any member organization in which a specialist is a partner or voting stockholder, from aequiring any interest or participation in any nonmember joint-account for buying or selling on the Exchange any security in which the specialist is registered. Attention is also directed to Rule 187 , which generally prohibits any specialist from effecting any off-theFloor transactions in any security in which he is registered, for any account in which he has an interest; and Rule 188, which prohibits any specialist from effecting any transaction in any other security traded at the post at which he is assigned as specialist.

Accordingly, each specialist who is directly or indirectly interested in an investment partnership should take the necessary steps to insure that these rules are observed. Amex Information Circular No. 79-69 at 8-9.

121. NYSE rule 460 .

122. The record must show the time sequence of transactions, and specialists are required to report such transactions on periodic call from the Exchange. Particular reporting requirements are imposed with respect to specialists who operate on a LIFO basis for valuing inventory and in the case of investment accounts. NYSE rules 104.12, 104.13 and supplementary material 104.50. The Amex has a similar requirement in rule 191 except that the report must be automatically filed with the exchange on a daily basis. See the text accompanying note 115 supra. 
auction market rules, ${ }^{123}$ and responsibility for loss if an order which should have been executed is not reported. ${ }^{124}$

One of the most important rules regulating the specialist, as well as other members, is the requirement that members and member organizations shall follow the principles of good business practice. ${ }^{125}$ This rule is potentially one of the most important rules regulating the specialist. It might be applicable where there would be a violation of principles of good businèss without another rule to directly fit the particular facts.

In the past, exchange surveillance of the specialist has been criticized as inadequate, ${ }^{126}$ although a number of exchange rules are - directed toward this function. For example, the specialist is required to keep a record of purchases and sales initiated on the floor "in stock in which he is registered, for an account in which he has an interest." 127 The recorded information must include the price, number of shares, time of transaction, and an indication if the sale is either a

123. The auction market at the specialist's post is conducted according to specific rules of priority, precedence, and parity. In all cases, the highest bid and the lowest offer prevail. NYSE rule 71 . The rules for priority, parity, and precedence where bids and offers are made at the same price are stated in NYSE rule 72.

A specialist may retain priority on a bid under rule 72(a), but when bidding for his own account to establish or increase a position he cannot have parity with an off-floor order or precedence based on size over such an order except in certain limited cases. NYSE rules 72(b), (c), (d), \& $112.24(\mathrm{~b})$.

124. NYSE rule I23.32 is an intricate rule allocating responsibility between the specialist and the customer's broker if the specialist fails to execute an order he should have handled. Regardless of the division of liability, query whether in the circumstances under this rule, there can be a limiting of any civil liability of the specialist to tbe public customer. It might be argued that the customer did not implicitly agree to the terms of rule 123.32 notwithstanding the fact that he had reason to believe the order would be executed on the floor of the NYSE. This theory assumes there is no implicit agrcement by a customer to aceept the contents of the NYSE rules. One may further question whether any negligence of the customer's broker in not promptly requesting, as he is expected to under tbe rule, the specialist for a status rcport is imputable under agency principles to the customer.

If the customer had explicitly agrced in a customer's agreement to be subject to NYSE rules it still does not automatically follow that rule $\mathbf{1 2 3 . 3 2}$ applies since there is a serious legal question whetber the small print of a customer's agreement could incorporate by reference all the rules of the NYSE which are themselves subject to change after the customer's agreement is executed.

125. NYSE rule 401 .

126. Surveillance of the specialist's activities was considered at length in the Special Study. The existing techniques of the excbanges were not considered adequate, and several recommendations for improvement were made including: investigation of an automated system for reconstruction of the specialist's book; rcgular reporting of specialist's income, categorized between brokerage and dealer income; and development of standards for evaluating the specialist's performance. SPECIAL STUDY, pt. 2, at 170-71.

127. NYSE rule 104.50 Supplementary Material. 
short sale or an opening sale and must be reported as requested by the Exchange. ${ }^{128} \mathrm{~A}$ designation indicates whether each transaction was on a plus tick, minus tick, zero plus tick, or zero minus tick. ${ }^{125}$ The specialist is also required to prepare a monthly report of his long position in his investment account. ${ }^{130}$

The exchange evaluates the specialist's activities through the information provided in these reports. One of the tests used is the "tick tesț" which has been discussed above; ${ }^{131}$ however, no objective criteria are established by the exchange rules to judge the results of the tick test, although the specialist is restricted from assigning specialty stock to an investment account unless he has maintained "a stabilization rate of at least $75 \%$, measured by the Tick Test . . . for the day of purchase, and for the entire calendar week encompassing that day."132 Both exchanges have assigned additional personnel for floor surveillance and have taken other steps to comply with the recommendations of the Special Study. ${ }^{133}$ However, NYSE specialists have recently been criticized for their performance and for their weak capital position. ${ }^{134}$

\section{Civil Liability}

The extent of civil liability for violations of exchange rules is a matter of considerable controversy ${ }^{135}$ and was litigated in Colonial

128. Id.

129. Id. A plus tick indicates a price above the immediately preceding transaction; minus tick is below the preceding transaction; zero plus tick is the same as the last transaction when the last price change was a plus tick; and a zero minus tick is the same as the last transaction when the last price change was on a minus tick. $I d$.

130. NYSE rule 104.12.

131. See note 18 supra and accompanying text. A particularly pertinent criticism made by the Special Study was that the NYSE closely reviewed each individual transaction, yet paid little attention to the overall effect of the specialist's activities. SPEC1al STUDY, pt. 2, at 101-06. NYSE rule 112(d)(3) contains a tick test for registered traders.

132. NYSE rule 104.12.

133. Release No. 7432, supra note 79, at 6-7.

134. See generally Fiske, Can the Specialist System Cope With the Age of Block Trading? InStitutional Investor, Aug. 1969, at 29. See also R. NeY, The Wall Street Jungle (1970).

135. See generally Lowenfels, Implied Liabilities Based Upon Stock Exchange Rules. 66 Colum. L. Rev. 12 (1966); Lowenfels, Private Enforcement in the Over-the-Counter Securities Markets: Implied Liabilities Based on NASD Rules, 51 CORNELL L.Q. 633 (1966). Lowenfels concluded that "to sustain private actions and impose liability for violations of exchange rules in certain limited areas is not only consistent with the legislative plan, but also necessary for the effectuation of the purpose underlying securities regulation-the protection of the investing public." 66 Colum. L. REv. at 30. See also Allen, Liability under the Securities Exchange Act for Violations of Stock Exchange Rules, 25 Bus. LAWYER 1493 (1970); Shipman, Two 
Realty Corp. v. Bache \& Co. ${ }^{136}$ Judge Friendly stated that

[a] particular stock exchange rule could ... play an integral part in SEC regulation . . . . TT]he court must look to the nature of the particular rule and its place in the regulatory scheme, with the party urging the implication of a federal liability carrying a considerably heavier burden of persuasion than when the violation is of the statute or an SEC regulation. The case for implication would be strongest when the rule imposes an explicit duty unknown to the Common Law. ${ }^{137}$

The Colonial case was followed by Buttrey v. Merrill Lynch, Pierce, Fenner \& Smith, Inc. ${ }^{138}$ where the issue was whether a violation of NYSE rule 405, the "know your customer" rule, gave rise to civil liability. The defendant argued that section 27 of the 1934 Act $^{130}$ granted jurisdiction to the federal court only for violations of either the Act itself or its rules and regulations and not rules of the NYSE. The court answered that "[ $[t]$ here is nothing inconsistent with this section in holding that violations of Rule 405 may be actionable as a 'duty created by this chapter' inasmuch as Rule 405 was promulgated in accordance with Sections 6 and 19 of the Act, even if Rule 405 is not in itself to be considered a rule "thereunder." "140 The Court then articulated a test to be used in determining whether there is implied civil liability:

The touchstone for determination whether or not the violation of a particular rule is actionable should properly depend upon its design "for the direct protection of investors." ...

Such a breach of fair practice undermines the protection of investors and surely "play(s) an integral part in SEC regulation" of Exchanges and their members. ${ }^{\text {it }}$

Another case after Buttrey is Aetna Casualty \& Surety Co. v. Paine, Webber, Jackson \& Curtis ${ }^{142}$ which involved stock certificates

Current Questions Concerning Implied Rights of Action Under the Exchange Act: Authority of the Administrative Agency to Negate; Existence for Violation of Self-Regulatory Requirements, 17 W. Res. L. Rev. 925, 963-1010 (1966); Note, Private Actions as a Remedy for Violations of Stock Exchange Rules, 83 HARV. L. REv. 825 (1970).

136. 358 F.2d 178 (2d Cir.), cert. denied. 385 U.S. 817 (1966). Since at least 1944, exchanges themselves, as distinguished from their members, have been held liable for a violation of their duty to enforce rules adopted pursuant to section 6 of the 1934 Act. Baird v. Franklin, 141 F.2d 238 (2d Cir.), cert. denied. 323 U.S. 737 (1944); Pettit v. American Stock Exchange, 217 F. Supp. 21 (S.D.N.Y. 1963).

137. Id. at 182.

138. 410 F.2d 135 (7th Cir.), cert. denied, 396 U.S. 838 (1969).

139. 15 U.S.C. $\S 78 \mathrm{aa}(1964)$.

140. 410 F.2d at 142 .

141. Id.

142. CCH FED. SEC. L. Rep. 92373 (N.D. I11, filed April 7, 1970). Motion for leave to file an amended complaint was granted on April 27, 1970. 
endorsed by the owners in blank with signatures guaranteed by a broker. An employee of the broker allegedly stole the certificates and, after several unsuccessful attempts to sell them, finally sold them through the defendants. The plaintiff based his suit in part on NYSE rule 405 . The court determined that rule 405 did not impose an obligation, based in part upon the conclusion that under the Uniform Commercial Code the securities were fully negotiable. In dictum the court stated that even if rule 405 did impose an obligation of care, "mere negligence" cannot be a ground for imposing civil liability under an exchange rule. Buttrey was distinguished on the grounds that its facts were "tantamount to fraud." However, the court's interpretation is open to doubt; although the court in Buttrey did state that the facts involved fraud, the standard articulated for civil liability did not require such a finding.

Assuming that a rule of an exchange may give rise to civil liability there is at the outset the issue whether any of the exchange standards applicable to specialists are "rules" at all. In this connection many of the provisions regulating specialists on both the NYSE and Amex are found in the supplementary material or commentary to the rules themselves. For example, much of the material concerning a specialist's transactions with the book or liquidating his position is found in the "Commentary" to Amex rule 170 while the analogous NYSE provisions are found in the rules themselves. In this regard the issue appears to be whether "commentary" or "supplementary material" is a rule. In DeRenzis $v$. Levy ${ }^{143}$ Judge Frankel stated in dicta that the test to be used is "at a minimum, [whether] the propositions in question were promulgated, recorded, and known as rules-or, at least, something closely approximating rules."144

143. 297 F. Supp. 998 (S.D.N.Y. 1969). In this case the Commission filed an amicus curiae brief in which it stated:

Similarly, private enforcement based upon violations of some stock exchange rules is necessary "to make effective the congressional purpose" and to provide a "necessary supplement" to the exchange's and the Commission's own action . . . .

.. In some areas the existence of a private right of action for damages might inhibit the self-regulatory body from promulgating new rules in areas beyond the Commission's own authority to do so. In others, the imposition of damages may actually impede rather than advance the self-regulatory purpose. Therefore, a careful examination must be made with respect to the particular rule to determine whether the implication of a private right of action would in fact further the overall objectives of the federal securities laws.

Brief for SEC as Amicus Curiae at 9-10, De Renzis v. Levy, id. (citations omitted).

144. 297 F. Supp. at 1001. Judge Frankel stated that there are "troublesome questions" as to the methods or procedures by which exchanges promulgate rules in view of the possible need that there be "minimal standards of notice" and a chance for affected persons to be "heard." Id. at $1001-02$ n.5. 
Clearly, any material which rule $\mathrm{l} l \mathrm{~b}-1$ requires to be an exchange rule would be considered as such whether or not labeled as a rule.

Once the barrier is crossed concerning the existence of a "rule," the issue becomes whether the rule plays an "integral part" in Commission regulation and is designed "for the direct protection of the investor." At the time of the promulgation of rule $1 \mathrm{lb}-1$ it might have been assumed that requiring the exchanges, as opposed to the Commission itself, to make the specialist's rule an exchange rule would shield the specialist from civil liability. However, with the Colonial and Buttrey cases this proposition appears to be incorrect. The different treatment of the negative Saperstein and positive obligation of the specialist under rule $1 \mathrm{lb}-1$ further complicates matters. Since both section 11 (b) of the 1934 Act and rule $11 \mathrm{~b}-1$ seem to give greater emphasis-at least by way of Commission enforcement- to the Saperstein approach it might seem that if there is the possibility of any liability under the Colonial and Buttrey tests then the stronger implication might result when the specialist disrupts the market. ${ }^{145}$ However, in view of the importance of the affirmative obligation to maintain an orderly market, this implication seems to be incorrect.

\section{RECENT DEVELOPMENTS}

The increasing percentage of institutional trades on the New York Stock Exchange has placed an unprecedented strain on the specialist system. More than 50 percent of public transactions on the exchange are currently represented by institutional orders, ${ }^{146}$ and the total of purchases and sales by such financial institutions was $\$ 80$ billion for 1969 and $\$ 65$ billion for 1968, a great increase over the 1967 total of $\$ 49$ billion. ${ }^{147}$ Accompanying this growth, large block transactions have continued to increase in number. Indeed, in 1968 block trades of 10,000 shares represented 10 percent of the total reported volume on the NYSE; for 1969 this ratio increased to over 14 percent. ${ }^{148}$ Paralleling this development is an increase in the average number of shares per sale printed on the NYSE tape. The average number of shares per sale was 257 in 1967, 302 in $1968,,^{149}$ and 356 for $1969 . .^{150}$

\footnotetext{
145. For a discussion of an NYSE rule which attempts to allocate responsibility for the failure to execute a customcr's order, see note 124 supra.

146. NYSE, PUblic TRansaction Study-1969 at 3 (1970).

147. New YoRK Stock EXChange 1970 Fact BoOK 48.

148. Id. at 12 .

149. Id. at 10.

150. Id. For the first three quarters of 1969 the average number of shares per sale was 367.
} 
The tremendous growth of institutional participation in the markets places an increasing burden on the specialist's capacity as dealer to meet the demands created by such large transactions. The specialist must stand ready within reasonable limits to purchase or sell from or to the public investor where temporary disparities occur in the public demand or supply and is expected to add depth to the markets. The task is obviously easier when he is dealing with the relatively small purchase and sales orders of the ordinary public investor. When large institutions attempt to purchase or sell blocks amounting to millions of dollars, a new magnitude of economic stress is placed upon the specialist. The former Chairman of the Commission, Manuel Cohen, stated that " $[t]$ he specialist was developed to provide liquidity and correct temporary imbalances in the supply and demand for particular stocks, and no longer can, alone, meet the large needs of the institutions."151 Ralph Saul, President of the American Stock Exchange, has expressed similar doubts about the capabilities of the existing specialist system to handle current market conditions. ${ }^{152}$

Growth of so-called block positioning member firms of the NYSE in recent years has resulted from the new needs of the institutional markets. Such firms have the capital, experience, and willingness to purchase large blocks from institutional sellers and sell positions so acquired in small pieces on the floor of the exchange. In the past year, a number of such firms have joined specialist units on the Amex and the NYSE. ${ }^{153}$ Such mergers or associations by the specialists and block positioning firms will increase the capital resources of specialists and perhaps better enable them to handle the increasing

NYSE, INSTITUTIONS AND THE STOCK MARKETS (1969). Thus there appears to be a slight decrease in the average shares per sale in the last quarter of 1969.

151. Address by SEC Chairman Cohen, American Bankers Ass'n, Feb. 11, 1969.

152. [I]t seems to me that we have to reexamine our specialist standards in light of underlying changes in our market-a process that is already underway. . . Is the specialist expected to buy an entire airline when a number of institutional portfolios decide to sell an airline stock and there are no substantial matching buyers? After an institution has aggressively purchased a stock and then immediately liquidates, does the specialist have an obligation to participate in depth to absorb portfolio sales? It would appear that his capital resources must be significantly increased over current levels in order to handle such transactions. Address by Amex President Ralph Saul, Jan. 1968.

153. The Wall St. Journal, Dec. 11, 1969, at 4, col.5; Washington Post, Jan. 9, 1970, § D, at 7, col. 6; N.Y. Times, Mar. 11, 1970, at 61, col. 3. Bear Stearns and Co. and Shields and Co. have already begun sharing specialists' books on the Amex. Five or six other firms are reported to have made application for specialist assignment on the Amex. In addition, Bear Stearns \& Co. now shares a joint account with a NYSE Specialist Firm. 
demands of institutional investors. If additional block positioning firms join specialist units, specially tailored exchange specialist rules may be required to facilitate the handling of block transactions in addition to whatever regulatory provisions are deemed necessary by the Commission. ${ }^{154}$

One of the issues raised by the growth of block transactions is whether block transactions fall within the scope of an auction market involving ordinary specialist activity. The Commission recently invited responses to certain questions resulting from the public investigatory hearings on the exchange commission rates. ${ }^{155}$ One of the questions asked was whether block transactions should be "excluded from the scope of any exchange rules which ... fix commission rates. . .. ."156 It was pointed out that the

question assumed the definition of a "block" transaction to be a transaction in which a member firm, by reason of the size of the order in relation to conditions in the exchange auction market, reasonably concludes that it is in the interest of the customer to search and negotiate for a matching interest on the other side of the market (including negotiating as principal with the customer) rather than to accept or submit a bid or offer in the ordinary course of the auction market. ${ }^{157}$

154. The Amex has recently announced that it is considering requiring block positioners to formally register as block traders so as to be more closely regulated. Wall St. Journal, June 10, 1970, at 40, col. 2. .

If many block positioning and other firms with public customers join specialist units, the exchanges may attempt to change NYSE rule 113 and Amex rule 190 which do not permit a specialist to have institutional customers. His competitors-block positioners and third market makers-have no such restriction. They are able to obtain commission busincss from institutions in the many cases where they find both sides to a transaction (such transactions where the broker-dealer, acting as agent, finds both buyer and seller, are commonly called crosses). It is very possible that rules 113 and 190 impose, therefore, a significant competitive disadvantage on the specialist. The third market firm and the block positioner may be morc able to position large blocks and do it as a service for their institutional clients because of the commission business they obtain on a regular basis from institutions. Furthermore, it is possible that institutions may give them easy crosses to handle to reward them for block positioning. Significant conflicts of interest which these rules were addressed to are discussed at note 99 supra and accompanying text.

The specialist who presently cannot have institutional customers may be less willing to position all or part of a large block since he may not receive direct commission business from institutions.

155. "A public hearing commenced on July 1,1968 as a fact-finding inquiry to obtain information relevant to the existing structure and level of commission rates of the nation's securities exchanges and to provide a basis for identifying and balancing the poliey and other considerations which lay behind those rates as well as an opportunity to assess proposals for change." SEC Securities Exchange Act Release No. 8791 at I (Dec. 31, 1969).

156. Id. at 4.

157. Id. 
The question raised the basic issue of whether block trades are negotiated trades falling outside the scope of the auction market and therefore outside the scope of exchange rules on fixed commissions. The negotiating is often done in the member firm's office and not on the floor of the Exchange, although the actual executing after a successful negotiation will take place on the floor of the exchange. Some observers feel that block trading and block positioning have no significant relationship to the auction market and belong rather to the negotiated over-the-counter market. ${ }^{158}$ The NYSE, on the other hand, believes that block transactions do belong to the auction market. ${ }^{159}$

Certain observers claim that the specialist could not be expected to continuously quote a bid and ask which is valid for huge blocks of stock. Moreover, to the extent a specialist positions a large block, he creates a conflict of interest, since he may be pressured to sell his block regardless of his obligation to sell only in a rising market. Furthermore, the large position may lessen his ability to enter the market as a purchaser pursuant to his obligation as a specialist.

The impact of institutionalization of the markets is beyond the scope of this article, but the subject is currently being researched by the Institutional Investors Study of the SEC. ${ }^{160}$ The pressures on the specialist structure are recognized to be enormous by representatives of the industry, and the future of the specialist system in its present form will depend upon methods developed to handle these pressures.

Another recent innovation is the growth of so-called computerized markets. One such market is the Institutional Networks Corporation or Instinet, a computerized system whereby institutions are able to trade with each other without the intervention of an exchange, a specialist, or a block positioning firm..$^{161}$ Direct sales between institutions have commonly been designated as the Fourth Market-a

158. In the third market a number of large broker-dealers who are not members of the NYSE make a market in NYSE listed stocks in competition with both the NYSE specialist and block positioners. These firms deal "net" with their customers and do not generally charge a commission. See generally Testimony of M.A. Shapiro, SEC Rate Strucutre Hearings 3904-4003 (1968); Testimony of First Boston Corp., id. at 3369-478; Testimony of Weeden \& Co., id. at 1459-1508, 4006-67.

159. See NYSE Memorandum in response to Release No.8791, supra note 155.

160. Pub. L. No. 90-438 (July 29, 1968). Congress stated that this study must include an evaluation of the effects of institutions upon the maintenance of fair and orderly securities markets.

161. For a general description of Instinet, see SEC Securities Exchange Act Release No. 8661 (Aug. 1, 1969). 
market where institution meets institution directly without the assistance of an exchange or a broker. This market, previously handled exclusively by telephone communications between institutions, can now also be handled via the 1 nstinet computer. ${ }^{162}$ The risk to the specialist is that the success and proliferation of such computerized markets may minimize the role of exchanges and specialists in this inscitutional trading. Moreover, the possibility of complete computerization of the specialist function also exists. ${ }^{163}$

\section{Conclusion}

The specialist is a key figure in the operations of the New York and American Stock Exchanges. $1 \mathrm{n}$ his role as dealer, which is the most important and most controversial of his two functions, he is expected to add depth and continuity to the auction market. The consensus of the exchanges and many economists has been that the specialist, acting as dealer, is vital to the maintenance of an orderly market. An orderly market, a term admittedly difficult to define, manifests several characteristics over the short-run: prices move in

162. In addition to. Instinet other automated trading systems have been established and placed into operation, for the block market. These two systems are described as follows:

Another automated trading information system is sponsored by AutEx Scrvice Corporation ("AutEx") . . . [and] would be available only to institutions and brokerdealers. It would allow the anonymous communication of indications of interest to buy or sell blocks of 1000 or more shares . . . . Unlike the Instinet system, the AutEx system as presently planned would not be programmed to allow actual negotiation or execution of transactions. Negotiations would be handled by broker-dealers. . . . Executions would be effected either on a national securities exchange or over-the-counter without reference to the system . . . .

The New York Stock Exchange also plans to sponsor an automated trading information system, called the Block Automation System ("BAS"). Member firms would be able to enter indications of interest in the BAS. An institutional subscriber could also enter an indication of interest, and in this latter respect BAS appears to be similar to Instinet. The institution would not, however, communicate directly with another institution and must designate a member of the New York Stock Exchange to act as its broker in any subsequent negotiations. As in the AutEx system, the planned BAS program would not allow negotiation or execution. Negotiations would have to take place between the two member brokers designated by the institutions, and executions would be subject to rules requiring exchange members' transactions to be effected on an exchange. Release No. 8661, supra note 161, at 1-2. All three systems are currently in operation.

163. One author suggested that "in a fully automated system the specialists" function must also be automated. This means the system must be programmed to maintain orderly markets without the intercession of the human element. The easiest way to do this is to have the exchange itself assume-the specialists' responsibility." Youngblogd, The A rgument for a Publicly Owned Stock Exchange, 1969 FinanCial ANAlysts J. 104A. 
small and continuous gradations; such minute price changes occur with respect to relatively large transactions as well as small---the market has depth; and the specialist is able and willing to step in as a significant buyer in falling markets and as a seller in rising markets. Moreover, the specialist is expected to solve the time discontinuity problem by virtue of his willingness to buy when no public buyer appears and to sell when no public seller appears. The underlying rationale is that the successful performance of the foregoing functions will improve the auction market, enhance public confidence in the operations of the market, and enable investors, at least in the shortrun, to buy or sell stocks promptly and at prices which are very close to that of the previous transaction. The rules of the exchanges and the Commission are designed to require specialists to fulfill the foregoing purposes.

Of crucial importance in any consideration of the specialist is the continuous exchange surveillance over his performance. The failure of specialists to enter a declining market, or the actions of specialists in selling long or short in bear markets, could, if not prevented or curtailed by proper surveillance, contribute to the public's lack of confidence. In a bear market, such derilictions would unnecessarily contribute to the cumulative build-up of investor concern. The important items to monitor in a surveillance program include, in addition to the continual review of specialists' performance in particular stocks on particular days, sufficiency of capital, profit and loss information, continuance of proper financing arrangements with banks and member firm creditors, and review of margin calls from creditors of specialists. The exchanges must obtain data on a current basis, and the Commission must be promptly informed of significant developments in these areas.

The specialist system is facing unique challenges. Various representatives of the securities industry representing different interests have attempted to predict future developments of varying kinds. The developers of Instinet hopefully anticipate a market in which institutions trade with each other without the use of specialists or exchanges. Third market makers criticize the ability of exchanges to handle blocks, predict the accelerated growth of their market, and call for liberalization of exchange rules which restrict members from dealing in the third market. The NYSE and Amex, on the other hand, believe that institutional trading belongs on the floor of the exchange and will continue to contribute to the depth and 
liquidity of the auction market in which specialists play a pivotal role. In this connection, they are considering an increased role for block positioning firms with specialists. In that case, the specialist rules which evolved to fit the needs of individuals may have to undergo profound changes to satisfy the new situation and the increasing role of block positioners. Even if the exchanges succeed in their efforts to bring and keep blocks on the floor of the exchange, the changes in - structure due to the growth of blocks may result in the growth of a situation which many feel currently exists-that is, two de facto separate markets, a negotiated market for blocks and the traditional specialist auction market for individuals. 